Jurnal Info Kesehatan

Vol.18, No.1, June 2020, pp.40-49

P-ISSN 0216-504X, E-ISSN 2620-536X

DOI: 10.31965/infokes.Vol18.Iss1.323

Journal homepage: http://jurnal.poltekeskupang.ac.id/index.php/infokes

R E S E A R C H

Open Access

\title{
Factors Influencing the Incident of Underweight Children Under Five Years in Sangihe Regency
}

\author{
Astri Juwita Mahihody ${ }^{1 a^{*}}$, Jelita Siska Herlina Hinonaung ${ }^{1 b}$ \\ ${ }^{1}$ Nursing Study Program, Department of Health, Politeknik Negeri Nusa Utara, Indonesia \\ ${ }^{a}$ Email address: mahihodyastri@gmail.com \\ b Email address: siskahinonaung@gmail.com
}

Received: 3 December 2019

Revised: 22 June 2020

Accepted: 25 June 2020

\begin{abstract}
Undernutrition can make children under five years vulnerable to diseases and can even cause death. One indication of children under five years suffering from malnutrition in children under five years is below the red line on the weight chart (underweight). This study aims to identify the factors that most influence the incidence of underweight in Sangihe Regency, North Sulawesi. This research was a quantitative analysis using a research methodology of a crosssectional sample. For this analysis, the sample was 165 respondents. These variables include education, jobs, income, and infectious diseases. The relationship between education levels, income, experience, and contagious diseases with underweight children was measured less using the chi-square test. In contrast, the determinants of underweight were identified using logistics regression. The results showed that the two most dominant factors that affected the incidence of underweight children under five years were occupational factors ( $p$-value $<0.001$ ) and knowledge factor ( $p$-value $<0.001)$. The other factors that might influence the cases of underweight children under five years are knowledge of feeding patterns and the number of children. Conclusion this research is Good knowledge is needed by mothers of children under five years in determining optimal nutrition for children under five years. For this reason, the mother's role is necessary for children under five to help the head of the family in finding additional income so that family nutrition, especially children under five, can be fulfilled.
\end{abstract}

Keywords: Underweight, Children, Factors, Influence

\footnotetext{
*Corresponding Author:

Astri Juwita Mahihody

Nursing Study Program, Department of Health, Politeknik Negeri Nusa Utara

Kesehatan Street, No.1 Tahuna, North Sulawesi, Indonesia

Email: mahihodyastri@gmail.com

(CThe Author(s) 2020. This article is distributed under the terms of the Creative Commons Attribution 4.0 International License (http://creativecommons.org/licenses/by/4.0/), which permits unrestricted use, distribution, and reproduction in any medium, provided you give appropriate credit to the original author(s) and the source, provide a link to the Creative Commons license, and indicate if changes were made. The Creative Commons Public Domain Dedication waiver (http://creativecommons.org/publicdomain/zero/1.0/) applies to the data made available in this article, unless otherwise stated.
} 


\section{INTRODUCTION}

Undernutrition in children under five years (0-59 months) is still a matter of grave concern. Malnutrition makes children under five years susceptible to disease and can even cause death. One indication of children under five years suffering from undernutrition in children under five years is below the red line on the weight chart (underweight). The World Health Organization (WHO) in 2017 shows that around 45\% of death of children under five years are related to undernutrition, and most of these problems occur in low and middle-income countries (WHO, 2017). The nutritional status of children under five years based on the weight-for-age index there are $3.8 \%$ of children under five years with poor nutritional status and $14.0 \%$ of children under five years with undernourished status (Kementerian Kesehatan R. I., 2018). The reported that in 2016 the percentage of children under five years with undernutrition in North Sulawesi was only 7.2\% while in 2017 the percentage reached 12.0\% (Kementerian Kesehatan R. I., 2018). This showed that the percentage of children under five years with undernutrition in North Sulawesi increased by $4.8 \%$ in 2017 . The nutritional status of children under five years based on the weight-for-age index in Sangihe Regency, North Sulawesi in 2017 showed that the percentage of undernourished children under five years was still quite high, namely by $13.1 \%$ while the percentage of children under five years with poor nutritional status, was as much as $2.6 \%$. The reported that there were 121 cases of children under five years with underweight in Sangihe Regency, North Sulawesi, and the highest was in the working area of the Lapango Health Center, which amounted to 31 cases (Dinas Kesehatan Kabupaten Sangihe, 2017).

Children under five years who are below the red line on the weight chart (underweight) are children under five years whose weight does not increase two times (T2) after being weighed. The Growth status of children under five years is not growing if the weight chart is horizontal or decreases cutting the growth line below it or the weight gain is less than the minimum weight gain (Kementerian Kesehatan R.I., 2010). Children under five years who are below the red line on the weight chart are a sign of danger that will ensure and determine further treatment for children under five years.

In Indonesia, factors related to the incidence of underweight in children under five years include the mother's behavior regarding feeding to infants, delay in initiation of early breastfeeding, types of complementary feeding, and infectious diseases. Poor maternal behavior regarding feeding children under five years is related to the incidence of underweight in children under five years (Sari, 2010). Late initiation of breastfeeding and complementary feeding are factors associated with underweight in children under five years. Nordang et al., (2015) stated that diarrheal disease, fever, and food shortages influence the incidence of underweight in children under five years. Novitasari et al., (2016) added that socioeconomic status is a factor associated with underweight on children under five years. The several factors that need to identify regarding the relationship with underweight in children under five in Sangihe Regency are knowledge, education level, occupation, income, and infectious diseases.

Public knowledge about nutrition in Sangihe Regency, North Sulawesi, is still lacking. The majority can see this of mothers providing adult food to their children under five years rather than giving them exceptional food under five years. Also, there is still an infant who has been given food, although they are still under six months (Dinas Kesehatan Kabupaten Sangihe, 2018). However, reports of maternal knowledge of underweight in children under five years have never been reported in Sangihe Regency. The percentage of mothers of children under five years from high school was 
$26.1 \%$, and elementary school graduates were about 24.6\% (Dinas Kesehatan Kabupaten Sangihe, 2017). The percentage of mothers of children under five years graduating from college, especially Diploma 2, was only $0.9 \%$. There were still $3.9 \%$ of mothers of children under five years who did not have a primary school diploma (Dinas Kesehatan Kabupaten Sangihe, 2018). According to Acquah et al. (2019), mother's education level is closely related to underweight in children under five years. The mother of children under five years with higher education level will be able to behave well in maintaining the health of their children under five years and can improve good behavior in feeding children under five years so that children under five years have a good nutritional status.

By type of activity in North Sulawesi Province in 2018, there were 25,216 people (15 years and over) is housewife's in Sangihe Regency, North Sulawesi (Badan Pusat Statistik Sulawesi Utara, 2018). Nigatu et al. (2018) mentioned that maternal work is a factor that is closely related to cases of underweight in children under five years. It was further explained that the characteristics of the Sangihe Regency, North Sulawesi, were still oriented to the primary sector, namely by directly utilizing natural resources. The lack of employment opportunities is a factor that is closely related to the underweight case in children under five years. The majority of income from the Sangihe Regency community depends on agricultural and fishery products. Around $60 \%$ of Sangihe Regency workers work as farmers and fishers (Badan Pusat Statistik Sulawesi Utara, 2018). Chowdhury et al. (2018) said that income was a risk factor that was strictly related to underweight in children under five years. Families with high-income levels would be better at providing good food for families.

According to the Central Bureau of Statistics in North Sulawesi (2018), the highest number of cases in the Sangihe Regency are infectious diseases such as diarrhea (1,435 cases) (Badan Pusat Statistik Sulawesi Utara, 2018). Illnesses caused by infections, including viruses, bacteria, and parasites, can interfere with metabolism and interfere with immune function. This can also cause weight loss. Children under five years suffering from infectious diseases have a risk of 5.688 times becoming underweight compared to children under five years who do not suffer from contagious diseases (Novitasari et al., 2016). Furthermore, Sinha et al. (2018) state that infectious diseases such as acute respiratory infections are risk factors for underweight in children under five years.

According to Pillitteri (2010) nurses play a role in maintaining optimal nutritional status for children under five years, correcting nutrient deficiencies in children under five years, helping mothers to follow care plans related to fulfilling nutrition for children under five years, and providing health education in meeting nutritional needs for children under five years. This study aims to identify the factors that most influence the incidence of underweight children under five years in Sangihe Regency, North Sulawesi. This research is essential because malnutrition in children under five years can cause death. In the case of underweight children under five years in Sangihe Regency, North Sulawesi is still quite high and needs dangerous handling from various parties. Research on factors related to the incidence of underweight children under five years, such as knowledge, education level, occupation, income, and infectious diseases, has never been conducted in Sangihe Regency, North Sulawesi. Therefore, the researcher is interested in determining the factors that influence underweight children under five years in Sangihe Regency, North Sulawesi. 


\section{RESEARCH METHOD}

This research was quantitative research using analytic survey research methods. The research design uses a cross-sectional survey. This research was conducted in the working area of the Lapango Health Center in June 2019. The sampling method is through stratified random sampling, with inclusion criteria, namely: (1) mothers who have toddlers aged 0-59 years, (2) mothers who can read and write, (3) mothers who can communicate well, and (4) mothers who are willing to be respondents. Exclusion criteria were: (1) toddlers who had chronic diseases such as malnutrition, HIV AIDS, and (2) Mothers who had not lived in the working area of the Lapango Health Center for less than one month. The total sample size is obtained by formula 2 , which is as follows: $\mathrm{n}=\left(\mathrm{Z}^{\wedge} 21-\alpha / 2 \mathrm{P}(1-\mathrm{P}) \mathrm{N}\right) /\left(\mathrm{d}^{\wedge} 2 \quad(\mathrm{~N}-1)+\mathrm{Z}^{\wedge} 21-\alpha / 2 \mathrm{P}(1-\mathrm{P})\right)$ with $\mathrm{n}=$ sample size, $\mathrm{N}=$ population size a number $637, \mathrm{Z} 21-/ 2=1,96, \mathrm{P}=$ proportion $(0.5), 1-\mathrm{P}=0.5$, and $\mathrm{d}=$ desired level of precision (0.05) (Lemeshow et al., 1990). The number of samples obtained was 150 respondents for anticipating a lack of samples, adding $10 \%$ of the total sample. Thus, the total sample is 165 respondents. The instrument in this study was in the form of a questionnaire. The knowledge questionnaire consisted of 13 items question. Knowledge questionnaires are arranged in the form of statements with choices the answers "right or wrong'. As for the favorable statement, the choice of answer is "right" is given a value of 1 , and the choice of "wrong" answers is given a value of 0 . Furthermore, the statement unfavorable for which the "wrong" answer choice is given a value of 0 , and the answer choice is "right," given a rating of 1 . Knowledge assessment is said to be good if the respondent meets a score of $\geq 10$, while knowledge is not good if it fulfills a score of $<10$. The education level questionnaire consisted of 2 , namely low and high. The level of education is low if not in school, elementary, or junior high. Higher education level if the last education graduated from high school or college. The job questionnaire consists of two, namely, work and not work. Works if the job is as a Civil Servant or Indonesian National Army or Police or private or entrepreneur. Does not work, namely the activity of mothers as housewives. The income questionnaire consisted of 2, namely <Regency Minimum Wage and Regency Minimum Wage. The $<$ Regency Minimum Wage is income $<$ Rp. 2,200,000 / month and $\geq$ Regency Minimum Wage, if the income $\geq$ Rp. 2,200,000 / month. The questionnaire underweight in children under five years consists of 2, namely yes and no. Answer yes, if children under five years experience underweight and answer no if children under five years do not experience underweight. Children under five years underweight are children under five years who are listed on the growth chart or register at the health center at a certain time.

Data analysis was in the form of univariate, bivariate, and multivariate analysis. The univariate analysis aimed to look at the distribution of data on all variables. The bivariate analysis aimed to see the relationship between the independent variables with the dependent variable using the chi-square test with a significance level of $\mathrm{p}<0.05$. The multivariate analysis aimed to see the variables that most influence the dependent variable. Variables analyzed in multivariate analysis, namely variables with $p$ values $<0.25$ in bivariate analysis. Multivariate analysis using logistic regression analysis with a backward stepwise method with significance level $\alpha=0.05$ and 95\% confidence level. Data are analyzed using SPSS version 17.0. Data collection was carried out after obtaining approval from the ethics commission earned from the relevant university No. 027/KEPK/V/2019. Also, data collection is done after obtaining permission from the respondent by signing an informed consent sheet. As in this study, researchers only listed the initials of respondents to maintain the confidentiality of respondents. 


\section{RESULTS AND DISCUSSION}

Table 1. Bivariate analysis by the level of education, occupation, income, knowledge, and infectious diseases.

\begin{tabular}{|c|c|c|c|c|c|c|c|}
\hline \multirow{3}{*}{ Variable } & \multicolumn{4}{|c|}{$\begin{array}{l}\text { Children under five } \\
\text { years underweight }\end{array}$} & \multirow{2}{*}{\multicolumn{2}{|c|}{ Total }} & \multirow{3}{*}{ p-value } \\
\hline & \multicolumn{2}{|c|}{ Yes } & \multicolumn{2}{|c|}{ No } & & & \\
\hline & $\mathrm{n}$ & $\%$ & $\mathrm{n}$ & $\%$ & $\mathrm{n}$ & $\%$ & \\
\hline \multicolumn{8}{|l|}{ Level of education } \\
\hline Low & 26 & 32.1 & 55 & 67.9 & 81 & 100 & \multirow[t]{2}{*}{$0.021 *$} \\
\hline High & 14 & 16.7 & 70 & 83.3 & 84 & 100 & \\
\hline \multicolumn{8}{|l|}{ Occupation } \\
\hline Not work & 10 & 10.4 & 86 & 89.6 & 96 & 100 & \multirow[t]{2}{*}{$<0.001^{*}$} \\
\hline Work & 30 & 43.5 & 39 & 56,5 & 69 & 100 & \\
\hline \multicolumn{8}{|l|}{ Income } \\
\hline $\begin{array}{l}<\text { Regency minimum } \\
\text { wage }\end{array}$ & 21 & 18.1 & 95 & 81.9 & 116 & 100 & \multirow[t]{2}{*}{$0.005^{*}$} \\
\hline $\begin{array}{l}\geq \text { Regency minimum } \\
\text { wage }\end{array}$ & 19 & 38.8 & 30 & 61.2 & 49 & 100 & \\
\hline \multicolumn{8}{|l|}{ Knowledge } \\
\hline Not good & 16 & 66.7 & 8 & 33.3 & 24 & 100 & \multirow[b]{2}{*}{$<0.001 *$} \\
\hline Good & 24 & 17.0 & 117 & 83.0 & 141 & 100 & \\
\hline \multicolumn{8}{|l|}{ Infectious diseases } \\
\hline Ever & 5 & 11.1 & 40 & 88.9 & 45 & 100 & \multirow[t]{2}{*}{$0.016^{*}$} \\
\hline Never & 35 & 29.2 & 85 & 70.8 & 120 & 100 & \\
\hline
\end{tabular}

*statistically significant $(\mathrm{p}<0.05)$

Table 1 shows that the variables significantly related to the incidence of children under the red line are the level of education with a p-value of 0.021 , employment with a value of $p<0.001$, income with a value of $p 0.005$, knowledge with a value of $p<0.001$, and infectious disease with a value of $\mathrm{p} 0.016$.

Table 2. The Multivariate analysis of factors that influence the incidence of underweight in children under five years

\begin{tabular}{lrrr}
\hline \multicolumn{1}{c}{ Variable } & OR & 95\% CI & p-value \\
\hline Level of education & 2.57 & $1.085-6.123$ & 0.032 \\
\hline Occupation & 0.22 & $0.092-0.544$ & 0.001 \\
\hline Knowledge & 6.01 & $2.037-17.756$ & 0.001 \\
\hline Infectious diseases & 3.23 & $1.027-10.173$ & 0.045 \\
\hline A Constant & 0.827 & & 0.770 \\
\hline$R$ Square $=0.363$ & & & \\
\hline
\end{tabular}

The variables are analyzed together in a multivariate analysis, namely the level of education, occupation, income, knowledge, and infectious diseases. Multivariate analysis using logistic regression with the backward stepwise method (likelihood ratio). The best model equation is considered with a p-value $<0.05$. Table 2 shows that the statistically significant variables in this study are education level with $\mathrm{OR}=2.57(95 \%$ CI: 1.085-6.123), occupation with OR $=0.22$ (95\% CI: 0.092-0.544), knowledge with $\mathrm{OR}=6.01$ (95\% CI: 2.037-17.756), and infectious diseases with OR $=3.23$ (95\% CI: 1.027-10.173). The most dominant variable influencing the incidence of underweight 
children under five years is knowledge and occupation. In addition, the results of the multivariate analysis also showed an $\mathrm{R}$ square value of 0.363 , which means that work and knowledge contributing to children under five years of cases were underweight of $36.3 \%$.

This study shows that there are more than half of respondents with low levels of education. The results of this study are consistent with Yuandari's (2012) research, which shows that the education level of mothers of children under five years who are underweight mostly has a low education level of $62.1 \%$. This study is in line with research conducted by Kusumaningtyas et al. (2017), which shows that overall mothers of children under five years who are underweight have primary education (93\%).

In this study, there are still mothers with low education levels, who do not complete elementary school or not attending school so that the toddlers tend to be below the red line. This study's results are consistent with Suryani's research (2017), which shows there is a relationship between maternal education and the nutritional status of children under five. According to Taludker (2017), mothers with higher education levels will have a better knowledge of children under five years of health and nutrition. Low education results in a lack of understanding of children under five years' mothers about food intake and proper nutrition for children under five years, causing an increase in malnutrition rates in children under five years.

The Mother's work is measured using closed questions. Based on the results of the study, it is found that most mothers do not work. From the results of statistical tests, it is found that there was a relationship between the work of mothers of children under five with cases of children under five underweight in the Work Area of the Lapango Health Center ( $p$-value <0.001). The results of this study are consistent with the research of Rezali \& Kristiani (2009), which shows that there is a significant relationship between Mother's work and the nutritional status of children under five.

In this study, it is found that most of the mothers do not work, which made it possible to guarantee the stability of family food security so that it affected the fulfillment of children under five years of nutrition. Mothers with low food security have an impact on the low availability of food rich in energy and nutrients. Thus, this can affect the health status of children. That is, children tend to have underweight (Mutisya et al., 2015). Also, there are still mothers who do not work with low education, making it difficult for mothers to absorb information so that they cannot meet a balanced nutritional intake for children under five years. According to Putri et al. (2015), mothers who do not work despite having a lot of time caring for their children under five years but if not supported by higher education will have difficulty receiving information about nutrition in infants. Thus, children under five mothers cannot apply good feeding practices to children under five years.

The results of this study are in accordance with Yuandari's (2012) research, which shows that under-five family income is underweight; most of them are classified as low income. The results of this study are in line with the research of Sari et al. (2018), which states that there is a relationship between family income and cases of underweight children under five.

In this study, it is found that most of the family heads work as farmers and fishers so that their income depends on the sales results. Also, some mothers of children under five years do not work to increase family income below the regency minimum wage. Thus, this can affect the fulfillment of family nutrition, including children under five years. According to Sari et al. (2018), the level of family income influences the 
purchasing of food to affect the nutritional status of children under five years. Also, Kusumaningtyas (2017) conclude that sufficient income will increase opportunities in buying quality food and the right quantity. However, if there is a decrease in income, the ability to purchase food can decrease both in terms of quality and quantity.

Mothers' knowledge is measured using a knowledge questionnaire that contained questions about mothers' knowledge about toddlers' nutrition. The results of this study indicate there are still mothers with imperfect knowledge. One crucial factor that affects the ability of mothers to manage resources to get adequate food is knowledge. Mothers' experience is an indirect cause of nutritional problems. Knowledge can be influenced by several factors, such as education and information sources (Yuandari, 2012).

This study is in accordance with Lestari et al. (2016) 's research, which shows that there is a relationship between the level of knowledge of mothers of children under five about nutrition with the incidence of underweight in Karangpasar Village, Tegowanu Health Center, Grobogan Regency. According to Notoadmojo (2014), knowledge can be obtained by someone naturally or intervened directly or indirectly, and most of the human knowledge is obtained through the eyes and ears. The level of knowledge can direct a person's behavior so that the level of mothers' knowledge about good nutrition will direct the Mother in providing food to their toddler (Lestari et al., 2016). Mothers' experience is needed to choose food, arrange a regular eating schedule, and create a positive environment in providing food. It can be an example for children in consuming diverse and healthy meals (Kleinman, 2009).

The results of this study are consistent with the research of Novitasari et al. (2016), which shows that there is a relationship between infectious diseases and cases of underweight children under five years. Children under five years with a history of contagious diseases in the past month have caused a decline in the nutritional status of children under five years. In line with the research of Wahyudi et al. (2014), data obtained that children under five years with infectious diseases can experience weight loss due to reduced appetite.

Multivariate analysis in this study shows that the most dominant factors affecting the incidence of underweight children under five years, namely knowledge and occupation. The R square value of 0.363 which indicates that the knowledge and work variables contribute to the incidence of underweight children under five years, which is equal to $36.3 \%$ while $63.7 \%$ is caused by other factors not included in this study. The other factors that might influence the cases of underweight children under five years are knowledge of feeding patterns and the number of children. At the time of data collection, most mothers did not know how to provide nutritious food for infants, and most mothers had more than two children.

This is in line with Mihretie's research (2018). It states that the Mother's knowledge about feeding patterns in children under five years is related to the nutritional status of children under five years. This feeding pattern includes the type and frequency of feeding according to the children under five age stage. In addition, the Mother's knowledge about the design of giving food to children under five years during illness and in the recovery period after illness as one of the causes of high underweight numbers in children under five years. According to the results of research by Woldeamauel \& Tesfaye, (2019), the number of children in the household is significantly related to underweight in children under five years. A large number of household members allow the fulfillment of food needs to be less so that children under five years can experience underweight. 


\section{CONCLUSION}

The results showed that the most dominant factors affecting cases of underweight children under five are knowledge and occupation. Right knowledge is needed by mothers of children under five in determining optimal nutrition for children under five years. Furthermore, even though the mother does not work or has a lot of time in caring for her children under five years, without being supported by a high level of education, they will have difficulty receiving health information, especially regarding nutrition so that the nutritional needs of children under five years are not met properly. Health workers, including nurses, need to increase the provision of health education on children under five nutrition for children under five' mothers. Thus, the knowledge of mothers of children under five years about proper nutrition for children under five years can increase. Also, the role of children under five' mother in helping the head of the family in finding additional income so that family nutrition, especially children under five, can be fulfilled. Researchers interested in this study can further examine the effect of the number of children and knowledge about feeding patterns on the incidence of underweight children under five.

\section{REFERENCES}

Acquah, E., Darteh, E. K., Amu, H., \& Adjei, D. K. (2019). Predictors of underweight in children under-five years in Ghana. Ghana medical journal, 53(1), 71-78. DOI: $10.4314 /$ gmj.v53i1.11

Badan Pusat Statistik Sulawesi Utara. (2018). Sulawesi Utara dalam Angka 2018. Manado: Badan Pusat Statistik Sulawesi Utara.

Chowdhury, T. R., Chakrabarty, S., Rakib, M., Saltmarsh, S., \& Davis, K. A. (2018). Socio-economic risk factors for early childhood underweight in Bangladesh. Globalization and health, 14(1), 14-54. DOI: https://doi.org/10.1186/s12992-0180372-7

Dinas Kesehatan Kabupaten Sangihe. (2017). Laporan Kasus Balita Bawah Garis Merah. Sangihe: Dinas Kesehatan Kabupaten Sangihe.

Dinas Kesehatan Kabupaten Sangihe. (2018). Profil Kesehatan Kabupaten Kepulauan Sangihe Tahun 2017. Sangihe: Dinas Kesehatan Kabupaten Sangihe.

Kementerian Kesehatan R.I. (2018). Buku Saku Pemantauan Status Gizi Tahun 2017. Jakarta: Direktorat Komunitas Nutrisi dan Direktorat Jenderal Kesehatan Masyarakat Kementerian Kesehatan.

Kementerian Kesehatan R. I. (2010). Peraturan Menteri Kesehatan Republik Indonesia Mengenai Penggunaan Kesehatan terhadap Kartu Menuju Sehat (KMS) untuk Balita. Jakarta: Kementerian Kesehatan Republik Indonesia Direktorat Jenderal Pengembangan Kesehatan Masyarakat.

Kleinman R. (2009). Pediatric Nutrition Handbook (6 ${ }^{\text {th }}$ ed.). Northwest: American Academy of Pediatrics.

Kusumaningtyas, D. E., Soesanto, S., \& Deliana, S. M. (2017). Pola Pemberian Makanan Terhadap Status Gizi Usia 12-24 Bulan pada Ibu Bekerja. Public Health Perspective Journal, 2(2). 155-167.

Lemeshow, S., Hosmer, D., Klar, J., \& Lwanga, S. (1990). Adequacy of Sample Size in Health Studies. New York: John Wiley \& Sons. 
Lestari, N. B., Sartono, A., \& Handarsari, E. (2016). Faktor-Faktor Yang Berhubungan Dengan Kejadian Balita BGM di Desa Karangpasar Wilayah Kerja Puskesmas Tegowanu. Jurnal Gizi, 5(1), 1-7.

Mihretie, Y. (2018). Maternal Knowledge on Complementary Feeding Practice and Nutritional Status of Children 6-23 Month in Jigjiga Town. Glob J Nutri Food Sci, $1(1), 1-12$.

Mutisya, M., Kandala, N. B., Ngware, M. W., \& Kabiru, C. W. (2015). Household food (in) security and nutritional status of urban poor children aged 6 to 23 months in Kenya. BMC public health, 15(1), 1-10. DOI: https://doi.org/10.1186/s12889-0152403-0

Nigatu, G., Woreta, S. A., Akalu, T. Y., \& Yenit, M. K. (2018). Prevalence and associated factors of underweight among children 6-59 months of age in Takusa district, Northwest Ethiopia. International journal for equity in health, 17(1), 1-8. DOI: https://doi.org/10.1186/s12939-018-0816-y

Nordang, S., Shoo, T., Holmboe-Ottesen, G., Kinabo, J., \& Wandel, M. (2015). Women's work in farming, child feeding practices and nutritional status among under-five children in rural Rukwa, Tanzania. British Journal of Nutrition, 114(10), 1594-1603.

Notoatmodjo S. (2014). Promosi Kesehatan dan Perilaku Kesehatan. Jakarta: Rineka Cipta.

Novitasari, Destriatania, D., Febry, F. (2016). Determinan Kejadian Anak Balita di Bawah Garis Merah di Puskesmas Awal Terusan. Jurnal Ilmu Kesehatan Masyarakat. 7(1),48-63.

Pillitteri, A. (2010). Maternal and Child Nursing: Care of The Childbearing and Childrearing family (6th ed). Philadelphia: Lippincott Williams \& Wilkins.

Putri, R. F., Sulastri, D., \& Lestari, Y. (2015). Faktor-Faktor yang Berhubungan dengan Status Gizi Anak Balita di Wilayah Kerja Puskesmas Nanggalo Padang. Jurnal Kesehatan Andalas, 4(1), 254-261. DOI: https://doi.org/10.25077/jka.v4i1.231

Rezali \& Kristiani. (2009). Hubungan antara karakteristik keluarga, pola asuh, dan asupan gizi dengan status gizi anak usia 0-36 bulan di kota Banda Aceh. Yogyakarta: S2 Ilmu Kesehatan Masyarakat Universitas Gadjah Mada.

Sari, D. P., Laenggeng, A. H., \& Tasya, Z. (2018). Hubungan Tingkat Pengetahuan Ibu Dan Status Ekonomi Keluarga Dengan Kejadian Anak Balita Bawah Garis Merah (BGM) Di Wilayah Kerja Puskesmas Nokilalaki. Jurnal Kolaboratif Sains, 1(1).79-86.

Sari M. (2010). Hubungan Perilaku Ibu tentang Pemberian Makanan dengan Angka Kejadian BRL pada Balita. Skripsi. Program Studi Pendidikan Dokter, Fakultas Kedokteran dan Ilmu Kesehatan,Universitas Islam Negeri Syarif Hidayatullah Jakarta.

Sinha, R. K., Dua, R., Bijalwan, V., Rohatgi, S., \& Kumar, P. (2018). Determinants of Stunting, Wasting, and Underweight in Five High-Burden Pockets of Four Indian States. Indian journal of community medicine : official publication of Indian Association of Preventive \& Social Medicine,43(4), 279-283. https://doi.org/10.4103/ijcm.IJCM_151_18

Suryani, L. (2017). Faktor Yang Mempengaruhi Status Gizi Balita Di Wilayah Kerja Puskesmas Payung Sekaki. Jomis (Journal Of Midwifery Science), 1(2), 47-53. 
Mahihody, A. J., \& Hinonaung , J. S. H. (2020). Factors Influencing the Incident of Underweight Children Under Five Years in Sangihe Regency. JURNAL INFO KESEHATAN, 18(1), 40-49.

Talukder, A. (2017). Factors associated with malnutrition among under-five children: illustration using Bangladesh demographic and health survey, 2014 data. Children, 4(10),1-8. DOI: https://doi.org/10.3390/children4100088

Wahyudi, B. F., Sriyono, S., \& Indarwati, R. (2014). Analisis Faktor yang Berkaitan dengan Kasus Gizi Buruk pada Balita. Jurnal Pediomaternal, 3(1), 83-91.

Woldeamanuel, B. T., \& Tesfaye, T. T. (2019). Risk factors associated with under-five stunting, wasting, and underweight based on Ethiopian Demographic Health Survey datasets in Tigray region, ethiopia. Journal of Nutrition and Metabolism, 2019, 1-11. DOI: https://doi.org/10.1155/2019/6967170

WHO. (2017). Malnutrition. Geneva: World Health Organization.

Yuandari, M. (2012). Gambaran Konseling Gizi Pada Balita Bawah Garis Merah (BGM) Berdasarkan Pedoman Konseling Gizi Depkes Ri Tahun 2008 (Studi Kasus di Pojok Gizi Puskesmas Sumbersari Jember). Skripsi. Gizi Kesehatan Masyarakat Fakultas Kesehatan Masyarakat Universitas Jember 